\title{
DEBATES
}

\section{The culture of time and the horizons of futurity}

\author{
A cultura do tempo e os horizontes da futuridade
}

\section{Francine Rossone de Paula}

\begin{abstract}
The inclusion of cultural differences in global studies has mostly taken the form of agendas that aim at recognition and democratization on the one hand, or a redemptive historicization on the other. What this paper argues is that a geohistorical reclamation of difference is insufficient to account for the possibility of a decolonial trajectory for humanity without a deeper understanding of the obstacles imposed by the present political economy of representations of "futurity". I explore the mobilization of futurity as a way to challenge what I refer to as necrochronopolitics, which I am defining as a range of mundane practices that facilitate the reproduction of death-worlds through the systematic erasure of bodies from 'acceptable' views of the future. By exploring Afrofuturism, Indigenous Futurism and Queer Futurism, I examine what these aesthetic manifestations reveal about the real and possible, and their disruptive capacities to inspire other time-space realities.
\end{abstract}

\section{Keywords}

Culture; Decoloniality; Global Politics; Futurism(s).

\section{Resumo}

A inclusão de diferenças culturais nos estudos globais tem assumido principalmente a forma de agendas que visam o reconhecimento e a democratização, por um lado, ou uma historicização redentora, por outro. O que este artigo argumenta é que uma recuperação geo-histórica da diferença é insuficiente para dar conta da possibilidade de uma trajetória decolonial para a humanidade sem uma compreensáo mais profunda dos obstáculos impostos pela atual economia política das representaçôes de "futuridade". Eu exploro a mobilização do futuro como uma forma de desafiar o que chamo de necrocronopolítica, que estou definindo como uma gama de práticas mundanas que facilitam a reprodução dos mundos da morte através do apagamento sistemático de corpos de visōes "aceitáveis" do futuro. Ao explorar o afrofuturismo, o futurismo indígena e o futurismo queer, examino o que essas manifestaçóes estéticas revelam sobre o real e o possível, e suas capacidades disruptivas de inspirar outras realidades espaçotemporais.

\section{Palavras-chave}

Cultura; Decolonialidade; Política Global; Futurismo(s). 


\section{Introduction}

Many scholars, activists and theorists have long been concerned with historical and contemporary manifestations of oppression and asymmetric relations of power that continually affect the experiences of individuals and groups in this world disproportionately. Postcolonial and decolonial thinkers' contributions to global studies have primarily focused on historical processes through which some groups have been racialized, gendered, and subordinated by others as well as on the effects of colonization and persistence of various forms of domination to this day. In their edited volume on Race, Gender, and Culture in International Relations, Randolph B. Persaud and Alina Sajed (2018, p. 2) have highlighted postcolonialism's role in investigating "[...] both the historical processes associated with European colonialism, and its impact on contemporary politics, such as immigration, globalization, development discourses and practices, nation-building, and foreign policy, among others". While reclaiming the past is an important step towards reestablishing presence that has been marginalized and invisibilized, a systematic analysis of a decolonial future-making is still imminent in most policy-oriented fields, particularly as policy-oriented approaches are mostly focused on the stabilization of progressive temporalities deriving from linear perceptions of history that favor certain trajectories to the detriment of others.

From a decolonial perspective, what Aníbal Quijano and Michael Ennis (2000) called "the new model of power of global vocation" has been established, according to them, by the conversion of two fundamental axes: the racialization of differences between conquerors and conquered and the "[...] constitution of a new structure of control of labor and its resources and products" (p. 533-534). Adding to this form of theorization that prioritizes geohistorical revisions, Walter Mignolo (2012, p. xxv) states in Local Histories/Global Designs the importance of looking at "[...] the spatial dimension imbedded in the modern world system that is lacking in the linear conception of modern Western history". Through this decolonial option, border thinking is "[...] from the perspective of subalternity [...] a machine for intellectual decolonization" (MIGNOLO, 2012, p. 45). The increasing interest in global studies for the inclusion of cultural difference has mostly taken the form of research projects that aims at recognition and democratization on the one hand, or a redemptive historicization on the other. Concepts like interculturality, co-existence, pluriversality, and relationality are all examples of these agendas. What this paper argues is that a geohistorical reclamation of difference is still insufficient to account for the possibility of different trajectories without a deeper understanding of the limitations imposed by 
current rules of intelligibility through which one becomes able to speak of and recognize a time yet to come.

Since September 11 attacks, polarization has grown significantly, and processes of 'othering' intensified. When it comes to entertaining visions of the future, studies of global politics have turned predominantly to notions of "[...] governing the future through targeted interventions in the present" (STOCKDALE, 2016, p. 176), favoring certain ideals of order, security, and stability through time over the perceived threat offered by the presence of difference and the possibility of other trajectories that are considered 'disruptive' or 'undesirable'. Therefore, cultural studies and postcolonialism should meet global politics beyond the recognition of difference and subordination in the past and the present, but also through a more explicit entertainment of different visions for humanity that takes seriously the way some bodies are persistently being eradicated from the future ${ }^{1}$.

Arjun Appadurai (2013), social-cultural theorist and anthropologist, invites us to see the future as a "cultural fact". According to him, the missing piece in cultural studies is a "[...] systematic effort to understand how cultural systems [...] frame the good life as a landscape of discernible ends and of practical paths to the achievement of these ends" (APPADURAI, 2013, p. 292). This should not imply that different cultural systems embrace temporality as linear or that 'futurity' features as a somewhat recognizable concept in all vocabularies and languages, but it means that habits of perception are inherently cultural and shape how different groups assimilate their existence as a collectivity in time. From the field of geography, Andrew Baldwin (2012, p. 172) contributes to this debate by arguing that the future " $[\ldots]$ can reveal important insights about the ways in which white geographies are configured that might otherwise be foreclosed if the past is privileged as the exclusive time-space through which such geographies are produced and maintained". We should not overlook the way certain images of 'the future of humanity' facilitate the reproduction of processes through which difference is continually erased. In the present, blackness, indigeneity, or queerness, for instance, face the threat of not belonging in the future, either physically as they are still disproportionally persecuted and killed in many societies, or figuratively, as they are denied presence in the dominant narratives and imaginaries of future.

\footnotetext{
${ }^{1}$ Decolonial thinkers are not oblivious to future possibilities, but they have emphasized "territories of difference" (ESCOBAR, 2008) and not engaged the future space as an explicit or primary concern.
} 
In this paper, I embrace Appadurai's understanding of 'future'2 as a significant element of culture and a space where violence and marginalization also take place. While future may be seen as the realm of the virtual, of the yet-to-come, the boundaries imposed on and by temporal imaginaries have profound and cruel material effects on the experience of individuals and groups who are denied presence in those depictions of a future space. On the understanding of the absence from representations and narratives of the future as being an existential threat, Jason Lewis, the director of the Initiative for Indigenous Future, explains that,

[...] our absence from the future imaginaries of the settler culture should worry us. Absence implies non-existence, or, at the very least, nonimportance. A people that are absent in the future need not be consulted in the present about how that future comes about. A culture that is assumed not to be important one hundred years from now can be discounted now, for what are the consequences? (LEWIS, 2014, p. 58 apud HICKEY, 2019, p. 166).

For Hickey (2019, p. 165), "[...] there is not enough discussion of the temporal elements of decolonial resistance - likely because temporality is often more abstracted and difficult to articulate". My argument in this paper is that temporality features as a very concrete realm of experience and does not need to be dealt with exclusively according to western philosophical and abstract existential articulations. In the next pages, I discuss the mobilization of futurity as a way to challenge what I refer to as necrochronopolitics, which I am defining as a range of mundane practices that facilitate the creation and reproduction of death-worlds through the systematic erasure of bodies from 'popular' or 'acceptable' views of the future. By exploring Afrofuturism, Indigenous Futurism and Queer Futurism, I discuss what these aesthetic manifestations reveal about where lines have been drawn between the real and possible and between those who are allowed to thrive and those who are constantly stopped from moving in this time-space reality. More importantly, this exploration shifts the discussion from one about western becomings ${ }^{3}$, predictions, diagnoses, and

\footnotetext{
${ }^{2}$ Understanding the future as a 'cultural fact' does not mean privileging forward-thinking cultures. Future, in this conceptualization, is linked to the possibility of social reproduction, of being able to imagine oneself existing 5 or 10 years from now.

3 The question of the "promise of the new" has been long explored in western philosophy. For an exploration of possibilities and becomings from a philosophical perspective, see Grosz (1999).
} 
management of reality based on the experience of those who have been occupying privileged spaces in history to one about resistance and the power of imagination born out of the experience of those who have been cast out of history and of the promises and imaginaries of what will have been.

\section{Futurity and Necrochronopolitics}

From October 2010 to March 2011, the Museum of London received the exhibition Postcards from the Future ${ }^{4}$. Robert Graves and Didier Mardoc-Jones explain that they wanted to "[...] create a space in which people can consider how climate change may impact on their lives" (quoted in THE PROJECT, 2012). As leading forces in photomontage imagery, the designers behind GMJ - a company that promises to "show you the future" juxtapositions of contemporary visual images with ideas and projections of what wellknown landscapes may look like in the years to come. The images include 'Parliament Square Water Crisis Centre', 'London as Venice', 'Skating at Tower Bridge', and one of most controversial depictions: the 'Buckingham Palace Shanty'.

The Buckingham Palace Shanty has been inspired by Tuca Vieira's photography of shanty towns in Brazil where the urban map exposes a stark contrast between rich and poor dwelling side by side. According to the designers, another source of inspiration was Kenyan shanty homes, from which they modeled up a sample of 90 homes that composed the final image depicting 20 million 'shanty dwellings' surrounding a protected and isolated palace that stands untouched by the crisis. While they aimed at showing a future in which Londoners would inevitably have to share the urban space with millions of climate refugees with the intention of shocking the audience into action against the effects of climate change, this illustration sparked a series of debates about how one end up reacting to the image of the mass of immigrants from the global South surrounding the palace and transforming the landscape. Groups representing refugees and asylum seekers called attention to what representations do by highlighting ways in which this type of imagery of the future reinforces stereotypes (VAUGHAN, 2010), potentially feeding the irrational fear against the imminent 'invasion' of Europe by the 'third world' and strengthening narratives and policies that have already been violently discriminatory.

\footnotetext{
4 A detailed description of the project and the stories behind each image can be found at http://www.postcardsfromthefuture.com/

5 To know more about the company run by Graves and Mardoc-Jones, the creators of the exhibition Postcards from the Future, see: https://www.gmj.net/
} 
Over ten years after this exhibition, in March 2021, Alex Hochuli wrote an article to the American Affairs entitled The Brazilianization of the World, where he pictures a very similar reality of the present while claiming that "the West's involution finds its mirror image in the original country of the future, the nation doomed forever to remain the country of the future, the one that never reaches its destination [...and] has been a byword for gaping inequality". By identifying the tendency within the 'West' of becoming more like Brazil, where walls and advanced security systems separate the elite from a population living in poverty (see AMAR, 2013), Hochuli (2021) adds that the "brazilianization of the world is our encounter with a future denied, and in which this frustration has become constitutive of our social reality". By comparing the 'Postcards from the Future' with the description offered by Hochuli, we can see that both interpretations - the prediction and the diagnosis of a future that has been interrupted - are based on a presumed knowing of this future space as well as an understanding of what it should have been instead. But how does one know the future when they see it? How are some images so easily read as denial of the future? What seems to be missing in those analyses is a more acute awareness of the connections between historical and contemporary effects of colonialism and the processes now associated with the denial of a 'progressive' future worldwide. It is not the case that the 'global North' is facing the risk of 'brazilianizing' as if 'brazilianization' was a virus spreading around the world from the 'global South' preventing an expected and desired forward-looking movement in advanced societies, but that historical intervention in those territories by colonial powers created the conditions for interrupted and denied futures in the first place. Moreover, Brazil should not be reduced to a single or a few experiences and realities. In this paper, I am not interested in challenging predictions about the future or to offer my own, but to engage futurity in its capacity to govern individuals and societies in the present (ANDERSON, 2010; BALDWIN, 2012), dictating the limits within which we are invited to discuss and identify possibility and feasibility. The function of the future, to echo Anna Agathangelou and Kyle Killians' (2016, p. 14) definition of the function of time, could also be understood as "[...] a limit, a resource, a site of exploration and ultimately antagonism".

In her essay about futurity as a keyword in American Cultural Studies, Rebecca Wanzo (2007, p. 119) describes the concept as consistently associated with identity, particularly in North America, "[...] linking ideas of what the future will look like with the belief that various groups can build a new space or, in our worst imaginings, be 
injured by an impending world that disavows or has no place for them". Futurity is the realm of imagination and anticipation, constantly shaped by the space a group believe to have for its actualization. While recognizing the condition of the future as an "exemplary of the virtual" (BALDWIN, 2012, p. 173), we are called to understand the way futurity, or the anticipation of being in the future, even in its permanent virtuality, has material effects on people in the here and now. What people imagine to be possible opens up the space for practices that actually make it possible, and the opposite is also true. Some examples of practices that render the future knowable and felt are highlighted by Ben Anderson (2010): “calculation", "imagination” and "performance". The three anticipatory logics through which these practices are often intervening in the present come in the form of precaution, pre-emption and preparedness ${ }^{6}$, but these are often practices that are the privilege of groups positioned on the side of the status quo, for whom the smooth unfolding of history into tomorrow should be protected. Unfortunately, this is not the case for groups who have not yet made it to colonized futures.

Mbembe (2003, p. 20) described colonial occupation as a "[...] matter of seizing, delimiting, and asserting control over a physical geographical area - of writing on the ground a new set of social and spatial relations". But it is worth noting that colonization has occupied more than physical geographical areas, denying the colonized presence or movement through time simultaneously. While "[...] space was [...] the raw material of sovereignty and the violence it carried with it" (MBEMBE, 2003, p. 26), the encounter between colonizer and colonized, or between self and other, could never happen fully in space after the temporal dislocation of the 'other' to the past. As Fabian (1982, p. xi) puts it, “[...] the 'other's empirical presence turns into his [sic] theoretical absence". In that sense, it is possible to imagine that historical and ongoing oppression has operated in conditions of "social death", a term first coined by sociologist Orlando Patterson in 1985 to refer to the "disposable status" of slaves. Elaborating on that, McCarthy (2020) explains that "[...] when slaves are stripped of

\footnotetext{
${ }^{6}$ In the field of International Relations, and particularly in the subfield of security studies, we find that the focus on the future is often associated with the anxiety with uncertainty and unpredictability. In the volume edited by Andrew Hom, Christopher McIntosh, Alasdair Mcday and Liam Stockdale, Time, Temporality and Global Politics, there is only one mention of futurity, in the conclusion, and it is in the context of "[...] how counterterrorism policy and practice express a certain politics of time that prioritizes the future over the present" (HOLMQVIST and LUNDBORG, 2016, p. 201). In Time, Temporality and Violence in International Relations published in 2016, Agathangelou and William advanced an agenda that started to connect temporality to different forms of violence in world politics.
} 
access to their own heritage and to the normal rights of kinship over their offspring and thus their future, they are natally alienated", what illustrates the work of violence and death through the interruption of timelines.

In Necrogeopolitics: On Death and Death-Making in International Relations, the editors claim that they insist on the "geo" in necrogeopolitics "[...] in order to show that spatial concreteness and materialities are very much part and parcel of instances of extra/ordinary death-making today" (ALPHIN and DEBRIX, 2020, p. 5). They add that "[...] spatial arrangements are crucial to the work of slow or soft killing, to endemic precariousness, or to banal or common modalities of vulnerability" (ALPHIN and DEBRIX, 2020, p. 5). While not denying or questioning the role of violent spatial configurations in the production and reproduction of social, cultural, political, and economic hierarchies, I suggest that this focus on space may obscure the ways in which the realms of space and time are always already connected, as it invisibilizes practices or policies and ideologies that enable, to the same extent, 'temporal configurations "[...] likely to facilitate and perpetuate mundane or nonexceptional forms of death making" (ALPHIN and DEBRIX, 2020, p. 6). However, in contrast to movements that seek to reclaim one's space exclusively through a revision of history and memorialization, the analyses that follow proposes a revision of the future as a crucial aspect of decolonial processes engaged in the reclamation of colonized territories. In the context of decolonization projects, the focus on colonial administration and national independence has largely failed. Decolonization can only be complete when one's sovereignty over and within a territory is accompanied by one's autonomy to shape their own temporal trajectories, to be included in the collective imaginary, what also implies considering obstacles and exclusions often imposed by 'national' representations privileging particular narratives of the past, the present and the future.

Fanon (1986[1952], p. 6), in Black Skin, White Masks, reminded us that "The future should be an edifice supported by living men. This structure is connected to the present to the extent that [he] consider the present in terms of something to be exceeded". In this case, we could clearly define the decolonial future as something that should be overtaken by those who have not been invited to be part of this construction. In the next section, I explore how an aesthetic approach to politics brings us the possibility of a reparation of the imagination and bodies wracked by violence. 


\section{Envisioning Futurity}

Drawing from Jacques Rancière's notion of images as fundamentally political, Bleiker (2018, p. 4) reminds us how images "[...] delineate what we, as collectives, see and what we don't and thus, by extension, how politics is perceived, sensed, framed, articulated, carried out and legitimised". By speaking of aesthetic sensibility as an expression of the "distribution of the sensible" (RANCIÈRE, 2004, p. 13), we also speak of arbitrary boundaries that are "accepted self-evidently as common sense" and separate what is politically acceptable from what is not (BLEIKER, 2018, p. 4). Thus, the easiness through each certain images of the 'future' circulate and are taken as inevitable is symptom of the normalization of a certain perception of the 'we' who gets to exist 'there'. In that sense, apocalyptic scenarios end up becoming the accepted depiction of a world where the 'other' has entered the imaginary space of the 'self in disruptive ways.

Images are granted meaning as they are interpreted in relation to other images and texts. This means that they do not 'make sense' by themselves but depend on individual and collective pre-conceptualizations and on an understanding of the norms surrounding us (BLEIKER, 2018). Looking at an image involves an inevitable invitation for it to be automatically processed cognitively according to the linguistic and symbolic resources available to us. For Barthes (1977), in opposition to a denoted message, which would be an almost perfect representation of a visual image - such as a photograph, the connoted message raises questions about how a particular representation fits the practices of knowledge and communication in a particular context. Beyond the image, other elements are necessarily considered, as worldviews embedded in the motivations, messages and/or aesthetic preferences communicated through these images. It is in this sense that one could affirm that images are always saying something about the world and how we view the world, as "witnesses of our time and of past times" (BLEIKER, 2018, p. 2-3), but also as prophets of possible future times.

Images are not only political in their origins and purposes, but mainly in their effects. Observing the relevance of the performativity of symbols and images, we consider the potential embedded in representations of "doing things" (BLEIKER, 2018). Movements like Afrofuturism, Indigenous futurism, and Queer futurism, in similar and different ways, engage the construction of future imaginaries that challenge familiar narratives derived from 'western' dreams of becoming, forcing us to recognize that which has been deemed unrecognizable through the linguistic and symbolic 
resources that predominate in the current political economy of aesthetic production and representation.

\section{Afrofuturism}

The term Afrofuturism was coined in 1994 by Mark Dery in the anthology Flame Wars: The Discourse of Cyberculture. His contribution, "Black to the Future", included interviews with Afrofuturist theorist Greg Tate, science fiction writer Samuel Delany, and scholar of contemporary black US culture and popular music Tricia Rose. Along with others, Dery documented the movement through which people of color started to be featured in science fiction and futuristic imaginations. The Special Issue on Afrofuturism in the journal Social Text, edited by Alondra Nelson, explored Afrofuturism's roots in late- $19^{\text {th }}$ and early $20^{\text {th }}$ century African American novels and the most recent manifestations enabled by digital communities and electronically mediated music, also expressed through photographs and poetry. The political possibilities of Afrofuturism have been registered in book-length format in 2013, by Ytasha Womack, but some of the most popular manifestations are found in artistic projects, from movies to performances in the street and exhibitions in physical and virtual galleries. In her assessment of the movement in Afrofuturism: the World of Black Sci-Fi and Fantasy Culture, Womack (2013, p. 124-125 apud SCOTT, 2021, p.7) elucidates that,

\footnotetext{
Afrofuturists redefine culture and notions of blackness for today and the future. Both an artistic aesthetic and a framework for critical theory, Afrofuturism combines elements of science fiction, historical fiction, speculative fiction, fantasy, Afrocentricity, and magic realism with nonWestern beliefs. In some cases, it's a total reenvisioning of the past and speculation about the future rife with cultural critiques.
}

In 2015, the artist and interactive designer Ayodamola Tanimowo Okunseinde (Ayo) created a gallery populated by documentation of his project "The Rift: An Afronaut's Journey". Okunseinde explains that he dressed as an 'Afronaut' to confront the misrepresentation of people of the African descent. He performed as Dr. Tanimowo predominantly in African American communities, such as Harlem, Fort Greene, and Bedford Stuyvesant. Throughout several different expeditions, the Afronaut travelled to these communities as an anthropologist from the future with the 
intention of understanding his past and of displaying " [...] a possible representation of the future for peoples of this current time-space" (OKUNSEINDE, 2015).

On the top of the page in this virtual exhibition, we find the following questions: "what does it mean to be seen yet unseen, to belong while being excluded, to exist in the penumbra... to be seen and see as alien... as 'the other"'? The collection of archeo-biological artifacts also implies that the Afronaut's journey's goal was to try and prevent the eventual collapse of his culture. According to Okunseinde (2015),

The Rift holds that the lack of representation of these peoples and their culture in current projections of the future pose an existential threat. It argues that the denial of this 'future space' distorts Africa's potential and denies the intrinsic human capacity of planning and organizing to its people. The effects of the above are an insidious erosion of the agency of the subject and their culture, and persistent alienation of their humanity.

It is worth noting that Ayo's gallery from 2020, five years later, is entitled "one and all" in allusion to the notice posted in Boston by abolitionist Theodore Parker in 1851 advising African Americans to avoid conversing with the watchmen and police officers due to the risk of conflict and abduction. In this exhibition, we are confronted with the image of panels with the inscription "CAUTION!! COULOURED PEOPLE of ...". In one of the photos, we can see a pile of different words on the ground, such as Sacramento, New York, Miami, Oklahoma City, and Chicago. The word collage on the panel advising on the dangers to this particular group is not linear and the letters are falling on the right, as if they were escaping legibility. Despite the ingenious and perhaps unintentional transition from the expeditions displayed in the 2015 gallery to the warning displayed in 2020, this "Afrofuturist sci-fi time-space speculative narrative and performance" (OKUNSEINDE, 2015) is still one of hope, as an invitation to engage our senses in different thinking and occupying affective dimensions of daily life (see ANDERSON and HOLDEN, 2008).

The Iyapo repository, co-founded and directed by Ayodamola Okunseinde and Salome Asega, is another example of the projection of people of African descent into the future. The collection of digital and physical artifacts was created to affirm and project the future of these people. Taking a more interactive and collaborative format, it "[...] asks us to reimage notions of race, identity and culture through technological artifacts as they [people of African descent] travel through time and place" (IYAPO REPOSITORY). The people participating in the project are offered a sheet of paper, the "Iyapo repository field notes", and invited to become resourceful scientists creating 
devices that may help humanity in facing some of its challenges. As we can check in Salome Asega's website, a select few of these artifacts are brought to life by the repository and added to the physical collection. An example of technology proposed by three participants that we can find in the gallery is called "Afromation", which consists of three kinds of pill that transmit information on historical topics: civil rights (dark green), the transatlantic slave trade (teal), and Rock \& Roll (yellow).

Winderson III (2016, p. 99) points out how slavery is "[...] an intrusion into language at the level of structure, as well as in its discursive performance". While "[...] the range of inscriptions within the unconscious remains open-ended, pregnant with futurity" (Winderson III, 2016, p. 99) for those granted the status of "Humans", Blackness has been historically "elaborated by social death", what justifies the relevance of the technology Afromation proposed by Nikki Lawrence, Nadia Marsh, and Lauren Nixon. Afromation indicates the relevance of historical revisionism, meaning the disentanglement of Blackness from the shackles of the past for the sake of the legibility of its projection into the future. However, a revision of the past is often not sufficient to elevate some groups into the status of being in the future or able to project their images and representations into the future. The author and playwriter Sunil Patel stated in episode 189 of the Geek's Guide to the Galaxy podcast that she "thought fantasy adventures were for the British schoolkids". Nalo Hopkinson, another author of science fiction and participant of this same episode recounts the story of when she started writing and initially imaged the "[...] default kind of fantasy - white people set in some part of Europe". Differently from the implantation of false memories in replicants in the movie Blade Runner for the sake of accommodating their emotions into a fabricated human consciousness, Afromation should empower afro descendants to reclaim the disowned past and to occupy future territories as their own.

In his discussion about the semantic differences and possible tensions between Afro and Black-futurism, Damion Kareen Scott (2021) brings our attention to the ways 'afro' and 'black' have been problematically referred to interchangeably based on an assumption that Black American subjectivity can be conflated with 'Africanness' in Afrofuturistic works. For the author, this can be attributed to the fact that the movement begun as "[...] subnational cultural movement with Black Americans as its primary subjects" (SCOTT, 2021, p. 144), even though it is now a transnational cultural movement that should be inclusive to 'afro' perspectives around the world while avoiding the pitfalls of universalism. On a different note, different studies have shown that the terminology matters as 'Black' has been more closely related to 
pejorative racialization processes and enslavement (see FAIRCHILD, 1985; HENDERSON, 2019). Henderson (2019, p. 44) notes that "[...] the Black experience in the United States settler colony is one primarily based in a systematic erasure of indigeneity from the enslaved African". One of the consequences of this systematic erasure of indigeneity may be the denial to Black Americans of reparations for state-sanctioned racial discrimination and slavery (RAY and PERRY, 2020), an experience shared by afro-descendants in other nations as well.

Afrofuturism recently became globally popular with the release of movies such as Black Panther (2018) and Black is King (2020). These are grounded upon narratives that move away from stereotypical characterizations of certain groups of people as 'broken' or socially dead, to use Patterson's term. Instead, historically marginalized people are depicted as healed, whole, and thriving in futuristic scenarios ${ }^{7}$. Whilst considering the need for material reparations and entertaining the possible risks attached to identity politics one assumes when embracing labels and categories, critics highlight that Afrofuturism has the potential to represent 'Africa' not as a site of inevitable future crisis and decline, but as a creative space (ESHUN, 2003, p. 292). This transnational movement that has been developed and attracted more artists and scholars over the past decades has also inspired the articulation of both Indigenous futurism and Queer futurism, movements that will be discussed in the next sections. For Scott (2021, p. 161), future subjects will benefit from a liberalized conception of futurism that is more open to transhumanistic and post-humanistic power dynamics, temporalities, and identities. I would argue that this is what binds and inspires the different aesthetic expressions of futurism developed from the perspective of those whose experiences have been shaped and represented predominantly by subalternity.

\section{Indigenous futurism}

For Tuck, McKenzie and McCoy (2014), “[...] any form of justice or education that seeks to recuperate and not interrupt settler colonialism, to reform the settlement and incorporate Indigenous peoples into the multicultural settler colonial nation-state is invested in settler futurity". In contrast, Hickey (2019, p. 166) has

\footnotetext{
${ }^{7}$ Dystopic futures are also very common in $\mathrm{Sci}-\mathrm{Fi}$, in which case the critique against oppressive pasts and presents is often projected into catastrophic futures (see, for instance, O segredo das Larvas, by Stêfano Volpe [2019], a dystopia happening in a meritocratic futuristic Brazil), but many artists and writers, such as Ayo, Suni Patel, and Salome Asega would reject 'Afro pessimism' translated into futurism to the extent that this confirms the expectation that black people are doomed to marginalization and exploitation.
} 
defined indigenous futurity as comprising "[...] the structures and narratives that support and image a future for Indigenous peoples". These structures and narratives are multiple but converge in the destabilization of the positioning of 'Indigenous' as overcome by history.

In 2012, Grace Dillon, an Anishinaabe scholar, coined the term indigenous futurism in her anthology Walking the Clouds: An Anthology of Indigenous Science Fiction. In the opening chapter, entitled "Imagining Indigenous Futurisms", Dillon (2012) claims to be paying homage to Afrofuturisms - which became an established topic of study for science fiction scholars - by mobilizing the term to articulate on indigenous experiences. She explains that "[...] historically, science fiction has tended to disregard the varieties of space-time thinking of traditional societies, and it may still narrate the atrocities of colonialism as 'adventure stories'" (DILLON, 2012, p. 2). The indigenous science fiction author Rebecca Roanhorse (2018) shared at the Uncanny Magazine that beyond encouraging "[...] Native, First Nations, and other Indigenous authors and creators to speak back to the colonial tropes of fiction", Indigenous Futurism

[...] also advocates for the sovereign. It dares to let indigenous creators define themselves and their world not just as speaking back to colonialism, but as existing in their own right. That is not to say that the past is ignored, but rather that it is folded into the present, which is folded into the future- a philosophical wormhole that renders the very definitions of time and space fluid in the imagination. (ROANHORSE, 2018).

It is about the past, present and future. In contrast to western science fiction's focus primarily on the future, indigenous futurism "[...] reflects all spacetimelines and sees how they are all connected" (LePensee, Anishibaabe scholar, artist, and game designer apud KEENE, 2018). One of the greatest misconceptions on indigeneity challenged by this aesthetic movement is that indigenous temporality is static. Indigenous people, to this day, are associated with an imaginary of the 'good or the bad savage', with certain dynamics of social reproduction that have prioritized 'preservation' and 'reservations' over autonomy and the possibility of transformation. In Brazil, for instance, an indigenous identity is strongly reliant on stereotypes and conditioned by an individual's relation to territory, what often results in the denial to urban indigenous communities of the recognition of their identity and their rights as they are not seen as 'pure' indigenous people (CIMI, 2011). This means that for many 
communities, the choice is between staying frozen in the past with their traditions, embracing the position offered to them within the grand scheme of things as 'natureloving creatures' that should be preserved, or to disappear as indigenous.

Fausto and Heckenberger (2007, p. 1), in their book about time and memory in indigenous Amazonia, highlight that "[...] whatever is eternal and immutable is out of time" and "indigenous peoples of lowland South America have often been depicted as being out of time - frozen in history, or unable or unwilling to conceptualize change as history". According to the dominant narratives, "Amazonian indigenous people have had the privilege (or misfortune) of changing little or not at all, reproducing themselves identically over time" (FAUSTO and HECKENBERGER, 2007, p. 1). In opposition to this denial of the future to indigenous peoples around the world, indigenous futurisms engage several artistic and scholarly initiatives invested in developing multiple visions of tomorrow where they feel alive and represented.

On the relationship between identity and change, Caroline Bynum (2001, p. 19) has suggested that "[...] if change is the replacement of one entity by another or the growth of an entity out of another entity in which it is implicit, we must be able to say how we know we have an entity in the first place". While we should be asking ourselves questions about unconscious criteria mobilized for the identification of a community, an image, a story, as 'Native' or 'Indigenous', it is also important to acknowledge the absence of indigenous representations in maps of the future. As Tuck, McKenzie and McCoy (2014, p. 16) remind us, "[...] replacement and emplacement, to be clear, are entirely concerned with settler futurity". In this case, we need to be cautious to not fall into the trap of accepting easy arguments favoring cultural relativization and hybridity as justifications for this 'absence'.

In Canada, Jason Lewis, University Research Chair in Computational Media and director of the Indigenous Future Imaginary initiative, along with indigenous curator and artist Skawennati Tricia Fragnito, respond to the existential threat created by the erasure of indigenous bodies in the future through asserting visions of thriving Indigenous peoples in the future. Their CyberPowWow project, conceived in 1996, has the major goal of overcoming these stereotypes about Aboriginal, Indigenous and Native people "[...] to help shape the World Wide Web; and to generate critical discourse - both in person and online - about First Nations art, technology, and community" (LEWIS and SKAWENNATI, 2005). On the main website, CyberPowWow is defined as "An Aboriginally determined territory in Cyberspace".

The CyberPowWow Project is part website and part what they refer to as "palace" or "[...] a series of interconnected, graphical chat rooms which allow visitors 
to interact with one another in real time". The virtual gallery contains artworks and texts created specifically for CyberPowWoW by Aboriginal artists and writers. Archer Pechawis, Co-Curator of CyberPowWow, explains that the project is a declaration of autonomous Aboriginal Space on the internet. All guests, both Indigenous and nonIndigenous, are invited to wear avatars created by Indigenous artists. The majority of these avatars are "Native", either real people or a depiction of "traditional Indians". This "Native" or "Indigenous" presence in the cyber space is significant when we contrast it with dominant 'worldviews'. For instance, at the virtual library on the website, Lee Crowchild shares a story entitled "How I see knowledge", a combination of short sentences and paintings in which he narrates how after the encounter with "Whiteman", they [the Whiteman] thought to have shaped the Natives into their own image.

In her work on visual culture and geographies of indigenous futurity, Amber Hickey (2019, p. 165) examines closely how the work of artists such as Skawennati (Mohawk) and Boonie Devine (Ojibwa/Anishinaabe) may have strong implications on discourses of temporality and Indigenous futurity, but also how "[...] they might point us toward counter-hegemonic temporal realities and decolonial futures". Skawennati and her collaborators, for example, created and added an Aboriginally determined research-creation network island called $\mathrm{AbTeC}$ to the virtual world Second Life. Users of Second Life can add to the virtual world and the creation of the island ensured the presence of First Nations in that space.

An important element of this project, in particular, is the narrative videos called 'machinimas' built into the Second Life platform. This series explores both Indigenous pasts and futures as the avatar is able to move across different physical and temporal geographies experiencing events in Indigenous people's history and imagination. Hunter, a Mohawk man from the future, is one of the avatars, or characters, starring the series. He uses TimeTravellerTM glasses to explore events in the past and in the future. Hickey highlights some affirmations and reactions that are attributed to Hunter in these films against popular western interpretations of historical events. Suspicious of how some stories are told as he travels through time, the Mohawk avatar observes: "If there's one thing every Indian knows it's this: when it comes to history, always get a second opinion" (apud HICKEY, 2019, p. 169). In one of these historical episodes, Skawennati expressed her intention to focus on Indigenous' women voices and views on the events at hand, but she reported having had difficulties finding direct quotes from Indigenous women in the past (HICKEY, 2019). As implied in the avatar's 
observation, "History" is suspiciously one-sided, and we are often confronted with gaps and silences as a result of violent processes of invisibilization.

As acknowledged before, Indigenous artists do not intend to simply revise history through this project but reimagine their presence in the present and projection into the future. The TimeTravellerTM glasses also take Hunter centuries ahead. In the future, he faces 'unexpected' images of wealthy indigenous people competing for Ferraris. Against the criticism Skawennati has received for depicting a future that has simply included wealthy Indigenous persons without challenging consumerism, she responded, in an interview with Hickey in 2018:

I am not showing the future, I'm showing a future. And I'm telling a certain story. The story I am telling is the story of how Native people got their groove back. [... I]t's only 75 minutes long, and so when you're telling a story like that you need - I need anyway - some sort of shorthand. Certain things in there I decided to use because everyone would get it. And so when you see them dancing for the prizes, it's still a freakin' car, it's still exotic travel. I know that, I know how it looks. But it was important because you never see Native people rich. We have to be poor to be truly Native - fuck that. And you know what Wab Kinew said?: 'I'mma live real lavish for all the times that you called my people savage.' And that's what I was thinking about (March 19, 2018 apud HICKEY, 2019, p. 170).

There are many layers to this debate. One the one hand, there is great value in challenging the image of Indigenous persons as inherently detached from modernity as a way of claiming Indigenous' rights to move through history and depict their future as they choose, in opposition to the traditional image of the poor nature-loving character frozen in time and doomed to be represented exclusively at museums and history books. On the other hand, the idea that time is perceived as having passed almost exclusively as we reach an image of 'futuristic' technologically advanced existence is highly questionable. However, it is worth noting that in Skawennati's narrative films, this linearity is significantly challenged when the story leads Hunter and another avatar to a pre-settler world. As Hickey (2019, p. 170) observes, the way the characters, meeting again Tenochtitlan, "[...] are dazzled by the beauty and efficiency of this pre-settler world" can be seen as a "clear challenge to normative understandings of the trajectory from 'uncivilized' to 'civilized' culture".

'Trajectorism' has been defined by Appadurai (2013, p. 225) as "the great narrative trap of the West", or more specifically, "[...] a deeper epistemological and 
ontological habit, which always assume that there is a cumulative journey from here to there, or more exactly from now to then, in human affairs, as natural as a river and as all-encompassing as the sky" (p. 223). The problem then with futuristic accounts of futurity is when the futuristic images are confused with empty promises of modernity and development that compel us to think that the entire world could be included in modern notions of 'good life' at certain point in the future, when in fact what we have seen is a destination "written in the image of Europe", with Europe being "unthinkable except as the singular expression of times arrow" that is expected to dominate the world (APPADURAI, 2013, p. 225). Modernization, beyond a set of culturally neutral predispositions, is inherently attached to particular cultural expressions (see LUKE, 1990) that have required the 'overcoming' of difference associated with 'wild' or 'untamed' nature in western imaginaries. Even though it is clear that many Indigenous people reject stereotypes and traditional images associating indigeneity with 'wildness', conditioning the future to docile or modernized versions of the 'other' is still highly problematic. In his study of three world-renowned twentieth-century musicians, Graham Lock (2000, p. 101) has exposed how these musicians, Sun Ra, Duke Ellington, and Anthony Braxton, were met with resistance and criticism for not meeting the white public's "false representations of blackness". The same observation could be made to any discomfort expressed in relation to indigeneity and expectations of how indigenous groups should present themselves in different parts of the world.

Different indigenous communities and indigenous nations do hold different experiences and understandings of temporality and contrasting views about what it means to talk about the unknown or about what has yet to happen, but they share the understanding that those initiatives that make them visible now, outside the museums and history textbooks, are key in resisting eradication. Against any conception that indigeneity turns primarily to the past, Bryan Kamaoli Kuwada (2015) asserts from Hawaii that all of their gathering

[...] practices and agricultural techniques, the patterned mat of lo'i kalo, the breath passing in and out of the loko i'a, the Kū and Hina of picking plants are predicated on looking ahead. This ensures that the land is productive into the future, that the sea will still be abundant into the future, and that our people will still thrive into the future. 
Thinking the future, much like thinking the past, is crucial to decolonization. Indigenous futurity protests narratives, images, and practices that prevent certain groups from recognizing themselves in depictions of 10 or 100 years from now. In addition to initiatives in the cyber space or in the form of novels and performances, Indigenous futurity can start to be promoted in very subtle and effective ways, as shown by Professor Damien Lee, who tweeted about how he replaces the phrase "in what is now Canada" when teaching indigenous history to "in what is currently Canada" (LEE, 2018), what shifts traditional temporal configurations and rejects the version of the end of history as told by western narrators. Small shifts like these are relevant in the work of making strange what has been normalized as future possibilities for humankind.

\section{Queer Futurity}

In their explorations of Queer futures, contributors to Dream Babes, a project featuring artists using speculative fiction as a medium for intersectional queer expression, argue that "History and science are parafiction". By that, they mean that it is "[...] patriarchal, colonial and capitalist storytelling reified into cultural metanarratives... Representation is reality, and in the face of representational violence, speculative fiction is a productive medium to invade existing narrative" (apud JAMESBAYLY, 2017). In this sense, we could confidently say that regardless of their different experiences with violence and exclusion, Afro, Indigenous and Queer futurities, which include their futuristic versions, share a mission to overcome their absence in the future, be it through challenging settler futurity, white futurity, or straight and heteronormative futurity. Whilst focusing on diverse experiences that could not be appropriately combined in a single or coherent narrative, embedded in the power structures of colonialism are the intersections of gender, sex, and race (LUGONES, 2013). Activists, writers, and artists are increasingly aware of the intersectional quality of the struggle for the decolonization of colonized spaces and times. Afro, Indigenous and Queer futurisms speak to brokenness and the dehumanization engendered by multiple layers of oppression stabilized by a coloniality of power.

In No Future: Queer Theory and the Death Drive, Edelman (2004) examines the role of the image of the child in straight futurity and connects queerness with this refusal of the social and political order. Edelman (2004, p. 30-31) asserts that "future is nothing but kid stuff', so 
[...] if the fate of the queer is to figure the fate that cuts the thread of futurity, if the jouissance, the corrosive enjoyment, intrinsic to queer (non)identity annihilates the fetishistic jouissance that works to consolidate identity by allowing reality to coagulate around its ritual reproduction, then the only oppositional status to which our queerness could ever lead would depend on our taking seriously the place of the death drive we're called on to figure and insisting, against the cult of the Child and the political order it enforces, [...] we do not intend a new politics, a better society, a brighter tomorrow, since all of these fantasies reproduce the past, through displacement, in the form of the future.

Because of the way the future has been associated historically with the natural unfolding of processes of social reproduction, Edelman's manifesto has been read as anti-futurist. Muñoz (2009, p. 25) sides with Edelman by explaining queer futurity as a "[...] stepping out of the linearity of straight time". Straight time is understood by him as "[...] self-naturalizing temporality that needs to be phenomenologically questioned [through] queer utopian hermeneutics" (MUNOZZ, 2009, p. 25). However, he also responds to Edelman's assertion that the future is the "province of the child and therefore not the queers" by arguing that "queerness is primarily about futurity and hope" (MUNOZZ, 2009, p. 11). Queerness must be seen, according to Muñoz, as only visible in the horizon, or in other words, "a doing for and toward the future” (MUNOZ, 2009, p. 1). As with Afrofuturism and Indigenous futurism, Queer futurism is about change. It is not only about thinking possibility, but about thinking possibility differently, beyond the boxes where culture and identities are currently put into.

Despite the optimism of some in relation to queering the future, we are warned against the dangers of assimilation of 'privileged queer' into the "hegemonic temporal trajectories of homonormativity” (RAO, 2020, p. 16; see also FREEMAN, 2010). For Heike Schotten (2018), assimilation obscures more radical agendas while nonassimilation equals accepting the precarity of the position of abject now translated into terrorist. In that sense, what should be noted is that a queer future will not be achieved through the simple presence of what has been accepted as 'aesthetic appealing' and 'domesticated' homosexuality or androgyny in futuristic productions. As queerness is constructed as unsettling 'primitiveness', the consequences of non-assimilation are the denial of the future and the emplacement of queer 'out of time' (RAO, 2020).

From this positionality, Zulfinkar Ali Bhutto/Faluda Islam defines themselves as an "[...] artist, performer, zombie drag queen, and curator of mixed Pakistani, 
Iranian and Lebanese descent" (BHUTTO, 2019). Faluda Islam is labelled a terrorist, "[...] a Muslim beaded drag queen turned revolutionary by the $21^{\text {st }}$ century" (BHUTTO, 2019). Along with other artists, such as Hushidar Mortezaie, Saba Taj, Jassem Hindin and Laylatul Qadr, Zulfinkar Ali Bhutto/Faluda Islam are part of “[...] a movement of artists from Muslim backgrounds [...] who envision the future landscapes through a queer lens" (BHUTTO, 2019). In this article to the Archer Magazine, Bhutto (2019) explained that "Queer Futurists do so with awareness that it can be an unknown space of potentially great fear, but also tremendous generosity" as they "[...] look at [their] multiple histories, cultures and legacies, which [they] cut up, carve, copy, corrupt and then cast into a future of [their] own imagining".

For Queer black abolitionist Adrienne Maree Brown (2017, p. 16), their “[...] work to change the world is 'science fictional behavior' - being concerned with the way our actions and beliefs now, today, will shape the future, tomorrow, and the next generations". Their own performances in the present are defined as 'fictional behavior', perhaps because they do not fit the dominant temporal and spatial narratives of the world as these are translated today. This may explain why there is not much on 'Queer futurism' that has not fallen victim of reproductive futurism, what brings us back to the initial question: How do we know the future when we see it? And how would we recognize a queer future?

\section{Conclusion}

We have been concerned with rewriting history as a form of redemption for the violence and the erasure of people from accounts of the past, but there is less movement towards an investigation of how the future remains white, heteronormative, and colonized. Understanding the future as a "culture fact" invite us to consider that death-making is not exclusively situated within analytical spatial frameworks. Necrogeopolitics and Necrochronopolitics are both useful concepts for an investigation of the conditions under which some bodies keep disappearing uneventfully, rendered invisible and/or denied their own trajectories.

Afrofuturism, Indigenous futurism, and Queer futurism involve aesthetic practices that bring these death-making practices to light, but that also explore futuremaking founded upon different scripts from those inherited from history. This paper did not intend to offer three separate representations of futurity or to exhaust conceptualizations of possibility. Rather, the few examples highlighted in this study aimed at challenging solutions to inequality and social injustice that are not fully open to imagination and reparation, and at leading deeper spatial and temporal 
restructurings. As Cruz and Rosario (2007, p. 748) point out, “[...] fiction is one of those last places where the world is bound between [the] pages, and you can sit with it for a while and imagine humanity in a completely different way".

I side with Shapiro $(2009$, p. 5$)$ in affirming that " $[\ldots]$ thinking $[\ldots]$ is not a matter of systematically achieving representations of experience by using reliable (that is, repeatable) techniques of observation. Rather, thinking involves resistance to the dominant modes of representing the world". These activists, scholars, performers and artists, are, in that sense of the word, thinking. This work is necessary if we want to bring to light not only the people rendered without history by colonization (see WOLF, 2010), but also those who are still not 'depicted' in the global future as writers of their own trajectories. To the same extent colonization would not have become a possibility without the double occupation of territories and of imaginaries of what is yet to come, decolonization will require both the reoccupation of territories and the resurrection of the socially dead into future temporalities. Beyond that, decolonizing western imaginaries could lead us out of the trap of always ending up either in apocalyptic or sterile high advanced technological white futures.

Francine Rossone de Paula é Professora na Queen's University Belfast. E-mail: f.rossonedepaula@qub.ac.uk.

\section{Referências}

AGANTHANGELOU, Anna M.; KILLIAN, Kyle D. Time, temporality and violence in international relations: (de)fatalizing the present, forging radical alternatives. London: Routledge, 2016.

ALPHIN, Caroline; DEBRIX, François. Introduction: necrogeopolitics and death-making. In: ALPHIN, Caroline; DEBRIX, François (Eds.). Necrogeopolitics: on death and death-making in international relations. London: Routledge, 2020. p. 1-14.

AMAR, Paul. The security archipelago: human-security states, sexuality politics, and the end of neoliberalism. Duke: Duke University Press, 2013.

ANDERSON, Ben. Preemption, precaution, preparedness: anticipatory action and future geographies. Progress in Human Geography, v. 34, n. 6, p. 777-798, 2010. doi: $10.1177 / 0309132510362600$

ANDERSON, Ben; HOLDEN, Adam. Affective urbanism and the event of hope. Space and Culture, v. 11, n. 2 , p. $142-159$, 2008. doi: $10.1177 / 1206331208315934$ 
APPADURAI, Arjun. The future as cultural fact: essays on the global condition. New York/London: Verso, 2013.

BALDWIN, Andrew. Whiteness and futurity: towards a research agenda. Progress in Human Geography, v. 36, n. 2, p. 172-187, 2012. doi: 10.1177/0309132511414603

BARTHES, Roland. Image, music, text. London: Fontana Press, 1977.

BHUTTO, Zulfikar A. Queer Muslim futurism. Archer Magazine, Feb 19, 2019. Available at: <https://archermagazine.com.au/2019/02/queer-muslim-futurism/>. Accessed: May 15, 2021.

BLEIKER, Roland. Visual global politics. London: Routledge, 2018.

BROWN, Adrienne M. Emergent strategy: shaping change, changing worlds. Chico, CA: AK Press, 2017.

BYNUM, Caroline W. Metamorphosis and identity. New York: Zone Books. 2001.

CONSELHO INDIGENISTA MISSIONÁRIO (CIMI). Relatório violência contra os povos indígenas no Brasil: dados de 2011. Brasília-DF: CIMI, 2011.

CROWCHILD, Lee. How I see knowledge. Who really constructed my worldview? Available at: <http://www.cyberpowwow.net/leeweb/index.html>. Accessed May 152021.

CRUZ, Angie; ROSARIO, Nelly. Angie Cruz in conversation with Nelly Rosario. Callaloo, v. 30, n. 3, p. 743-753, 2007. doi: 10.1353/cal.2008.0014

CYBERPOWWOW. About. Available at: <http://www.cyberpowwow.net/about.html>. Accessed: May 15, 2021.

DILLON, Grace (Ed.). Walking the clouds: an anthology of indigenous science fiction. Tucson: The University of Arizona Press, 2012.

EDELMAN, Lee. No Future: Queer theory and the death drive. Durham, NC: Duke University Press, 2004.

ESCOBAR, Arturo. Territories of difference: place, movements, life, redes. Durham, NC: Duke University Press, 2008.

ESHUN, Kodwo. Further considerations on Afrofuturism. CR: The New Centennial Review, v. 3, n. 2, p. 287-302, 2003. doi: 10.1353/ncr.2003.0021

FABIAN, Johannes. Time and the Other: how anthropology makes its object. New York: Columbia University Press, 1983.

FAIRCHILD, Harold H. Black, Negro, or Afro-American? The Differences Are Crucial! Journal of Black Studies, v. 16, n. 1, p. 47-55, 1985. Available at: <https://www.jstor.org/stable/2784105>. Accessed: Nov. 11, 2021.

FANON, Franz. Black skin, white masks. Transl. Charles L. Markmann. London: Pluto Press, 1986.

FAUSTO, Carlos; HECKENBERGER, Michael. Introduction. Indigenous history and the history of the "Indians". In: FAUSTO, Carlos; HECKENBERGER, Michael (Eds.). Time and memory in indigenous Amazonia: anthropological perspectives. Gainesville: University Press of Florida, 2007. p. 143.

FREEMAN, Elizabeth. Time binds: Queer temporalities, Queer histories. Durham, NC: Duke University Press, 2010.

GROSZ, Elizabeth. Becoming: explorations in time, memory, and futures. Ithaca, N.Y.: Cornell University Press, 1999.

HENDERSON, Kelly L.-T. "I had never been at home in the world": a case for Black-Indigenism. Curriculum Inquiry, v. 49, n. 1, p. 44-64, 2019. doi: 10.1080/03626784.2018.1556562 
HICKEY, Amber. Rupturing settler time: visual culture and geographies of Indigenous futurity. World Art, v. 9, n. 2, p. 163-180, 2019. doi: 10.1080/21500894.2019.1621926

HOCHULI, Alex. The brazilianization of the world. American Affairs, v. 5, n. 2, May 2021. Available at: <https://americanaffairsjournal.org/2021/05/the-brazilianization-of-the-world/>. Accessed: May 15, 2021.

HOLMQVIST, Caroline; LUNDBORG, Tom. Conclusion. In: HOM, Andrew; MCINTOSH, Christopher; MCDAY, Alasdair; STOCKDALE, Liam (Eds.). Time, temporality and global politics. Bristol: E-International Relations, 2016. p. 193-206.

IYAPO REPOSITORY. Salome Asega. Disponível em: <http://www.salome.zone/iyapo-repository>. Accessed: May 15, 2021.

JAMES-BAYLY, Savannah. From Queer to eternity: Queer futurism in modern media. The Spread: A magazine for all things film, 2017. Available at: <http://cinemajam.com/mag/features/queerfuturism>. Accessed May 15, 2021.

KEENE, Adrienne. Wakanda forever: using indigenous futurisms to survive the present. Native Appropriations, 2018. Available at: <https://nativeappropriations.com/2018/02/wakanda-foreverusing-indigenous-futurisms-to-survive-the-present.html>. Accessed May 15, 2021.

KUWADA, Bryan K. We live in the future. Come join us. Ke Kaupu Hehi Ale, 2015. Available at: <https://hehiale.com/2015/04/03/we-live-in-the-future-come-join-us/>. Accessed May 15, 2021.

LEE, Damien. When I write, I avoid the phrase “...in what is now Canada.” I use “...in what is currently Canada" to open possibilities for imagining futurities beyond the settler state. Nogojiwanong, Jan 31, 2018. Twitter: @damienlee. Available at: <https://twitter.com/damienlee/status/958698343135244288>. Accessed: May 1, 2021.

LEWIS, Jason; SKAWENNATI, Tricia F. Aboriginal territories in cyberspace. Cultural Survival Quarterly, v. 29, n. 2, Jun. 2005. Available at: <https://www. culturalsurvival.org/publications/culturalsurvival-quarterly/aboriginal-territories-cyberspace>. Accessed: May 15, 2021.

LOCK, Graham. Blutopia: visions of the future and revisions of the past in the work of Sun Ra, Duke Ellington, and Anthony Braxton. Durham, N.C.: Duke University Press, 2000.

LUGONES, Maria A. Peregrinajes/pilgrimages: theorizing coalitions against multiple oppressions. Lanham, Maryland: Rowman and Littlefield, 2003.

LUKE, Tim. Discourses of modernization and development: theory and doctrine after 1945. In: LUKE, Tim. Social theory and modernity: critique, dissent, and revolution. London: Sage Publications, 1990. p. 211-240.

MCCARTHY, Jesse. On Afropessimism. Los Angeles Review of Books, 2020. Available at: $<$ https://lareviewofbooks.org/article/on-afropessimism/>. Accessed: May 15, 2021.

MBEMBE, Acquiles. Necropolitics. Trans. Libby Meintjes. Public Culture, v. 15, n. 1, p. 11-40, 2003.

MIGNOLO, Walter. Local histories/global designs: coloniality, subaltern knowledges, and border thinking. Princeton: Princeton University Press, 2012.

MUNOZ, José E. Cruising utopia: the then and there of Queer futurity. New York: New York University Press, 2009.

OKUNSEINDE, Ayodamola Tanimowo (AYO). The rift: an afronaut's journey. AYO.IO, 2015. Available at: <http://www.ayo.io/rift.html>. Accessed May 152021. 
PATTERSON, Orlando. Slavery and social death: a comparative study. Cambridge, MA: Harvard University Press, 1982.

PECHAWIS, Archer. Not so much a land claim. CyberPowWow. Available at: <http://www.cyberpowwow.net/archerweb/index.html>. Accessed May 152021.

PERSAUD, Randolph B.; SAJED, Alina. Introduction: race, gender, and culture in International Relations. In: PERSAUD, Randolph B.; SAJED, Alina (Eds.). Race, gender, and culture in international relations. London: Routledge, 2018. p. 1-18.

QUIJANO, Aníbal; ENNIS, Michael. Coloniality of power, Eurocentrism, and Latin America. Nepantla: Views from South, v. 1, n. 3, p. 533-580, 2000.

RANCIÈRE, Jacques. The politics of aesthetics. Trans. Gabriel Rockhill. London: Bloomsbury, 2004. RAO, Rahul. Out of time: the Queer politics of postcoloniality. Oxford: Oxford University Press, 2020.

RAY, Rashawn; PERRY, Andre. Why we need reparations for Black Americans. Policy 2020 Brookings, Apr. 2020. Available at: <https://www.brookings.edu/wpcontent/uploads/2020/04/BigIdeas_Ray_Perry_Reparations-1.pdf>. Accessed: August 28, 2021.

ROANHORSE, Rebecca. Postcards from the apocalypse. Uncanny: A magazine of science fiction and fantasy, 2018. Available at: <https://uncannymagazine.com/article/postcards-from-the-apocalypse/>. Accessed: May 15, 2021.

SCHOTTEN, C. Heike. Queer terror: life, death, and desire in the settler colony. New York: Columbia University Press, 2018.

SCOTT, Damion K. Afrofuturism and Black futurism: some ontological and semantic considerations. In: BUTLER, Philip (Ed.). Critical Black Futures. Singapore: Palgrave Macmillan, 2021. p. 139-163.

SHAPIRO, Michael J. Cinematic geopolitics. London: Routledge, 2009.

STOCKDALE, Liam P. D. Catastrophic futures, precarious presents, and the temporal politics of (in)security. In: HOM, Andrew et al. (Eds.). Time, temporality and global politics. Bristol: EInternational Relations, 2016. p. 176-192.

THE PROJECT. Postcards From the Future - the project, 2012. Available at: <http://www.postcardsfromthefuture.com/2012/06/08/postcards-from-the-future/>. Accessed May 15, 2021.

TUCK, Eve; MCKENZIE, Marcia; MCCOY, Kate. Land education: Indigenous, post-colonial, and decolonizing perspectives on place and environmental education research. Environmental Education Research, v. 20, n. 1, p. 1-23, 2014. doi: 10.1080/13504622.2013.877708

VAUGHAN, Adam. Images of London after climate change 'are lazy', say refugee groups. The Guardian, Oct. 27, 2010. Available at: <https://www.theguardian.com/environment/2010/oct/27/future-london-climate-change-images>. Accessed: May 10, 2021.

VOLPE, Stêfano. O segredo das larvas. Rio de Janeiro: Letras e Versos, 2019.

WANZO, Rebecca. Futurity. In: BURGETT, Bruce; HENDLER, Glenn (Eds.). Keywords for American cultural studies. New York: NYU Press, 2007. p. 119.

WILDERSON III, Frank B. Doing time in the (psychic) commons: Black insurgency and the unconscious. In: AGANTHANGELOU, Anna M.; KILLIAN, Kyle D. Time, temporality and violence 
in international relations: (de)fatalizing the present, forging radical alternatives. London: Routledge, 2016. p. 87-103.

WOLF, Eric R. Europe and the people without history. $2^{\text {nd }}$ ed. California: University of California Press, 2010.

Texto recebido em 28 de outubro de 2021. Aprovado em 17 de novembro de 2021. 